\title{
PEMANFAATAN BUAH NAGA SUPER MERAH (Hylocereus costaricensis) DALAM PEMBUATAN JENANG DENGAN PERLAKUAN PENAMBAHAN DAGING BUAH YANG BERBEDA
}

\author{
Oleh: \\ Rekna Wahyuni *) \\ *) Tenaga Pengajar Universitas Yudharta Pasuruan
}

\begin{abstract}
Abstrak
Buah naga super merah (Hylocereus costaricensis) selain dikonsumsi dalam bentuk segar juga diolah menjadi beberapa produk olahan untuk mempermudah mengkonsumsi karena buah naga adalah buah yang mengandung kadar air tinggi maka bersifat muda rusak oleh karena itu banyak orang yang membuat olahan buah naga untuk mengurangi jumlah kerugian, adapun produk olahan yang diminati antara lain dodol, sirup, dan kripik buah naga super merah (Hylocereus costaricensis).

Rumusan masalah dari penelitian ini adalah apakah ada pengaruh proporsi penambahan daging buah naga super merah (Hylocereus costaricensis) terhadap kualitas jenang yang dihasilkan dan berapakah proporsi daging buah yang paling baik sehingga menghasilkan jenang buah naga super merah (Hylocereus costaricensis) yang berkualitas.

Tujuan penelitian adalah untuk mengetahui pengaruh proporsi penambahan daging buah naga super merah (Hylocereus costaricensis) terhadap kualitas jenang yang dihasilkan dan untuk mengetahui proporsi daging buah yang paling baik sehingga menghasilkan jenang buah naga super merah (Hylocereus costaricensis) yang berkualitas.

Percobaan dilakukan dengan menggunakan rancangan acak kelompok (RAK) dengan 5 perlakuan dan masing - masing perlakuan diulang sebanyak 3 kali. Pengumpulan data dilakukan dengan melakukan analisis karakteristik kimia yaitu kadar air dan; karakteristik fisik tekstur/kekenyalan dan karakteristik organoleptik yaitu kesukaan terhadap warna, rasa, kekenyalan dan aroma.

Kesimpulan yang dapat diambil dari penelitian ini adalah terdapat pengaruh proporsi penambahan daging buah naga super merah (Hylocereus costaricensis) terhadap kualitas jenang yang dihasilkan
\end{abstract}


yaitu semakin banyak proporsi penambahan daging buah naga super merah (Hylocereus costaricensis) maka kualitas jenang yang dihasilkan semakin baik.

Proporsi penambahan daging buah naga super merah (Hylocereus costaricensis) yang paling baik adalah perlakuan A5 yaitu proporsi penambahan daging buah naga super merah sebesar 50 gr dengan karakteristik kadar air sebesar 58,977\%; tektur 8,67 mm; nilai kesukaan rasa 5,85 nilai kesukaan warna 5,90; nilai kesukaan aroma 4,65 dan nilai kesukaan tekstur 5,40.

Kata kunci: buah naga super merah, jenang, daging buah

\section{PENDAHULUAN}

Buah naga termasuk dalam buah yang eksotik karena penampilannya yang menarik, rasanya asam manis menyegarkan dan memiliki beragam manfaat untuk kesehatan. Manfaat buah naga menurut Marhazlina (2008) dalam penelitiannya adalah sebagai anti hiperkolesterolemik, sedangkan Pedreño dan Escribano (2001) menyatakan bahwa buah naga berpotensi sebagai anti radikal bebas karena mengandung betasianin.

Buah naga yang paling diminati konsumen dewasa ini adalah jenis buah naga super merah (Hylocereus costaricensis) karena buah naga super merah memiliki rasa lebih manis tanpa rasa langu dibanding jenis lainnya dan diyakini lebih berkhasiat untuk kesehatan tubuh dan memiliki warna yang menarik (Anonymous, 2009). Hal ini ditunjang oleh riset yang dilakukan oleh Marhazlina (2008), peneliti Department of Nutrition and Dietetics Faculty of Medicine and Health Sciences Universiti Putra Malaysia yang menyatakan bahwa buah naga super merah berpotensi membantu menurunkan kadar gula darah dan mencegah risiko penyakit jantung pada pasien diabetes.

Buah naga super merah (Hylocereus costaricensis) selain dikonsumsi dalam bentuk segar juga diolah menjadi beberapa produk olahan untuk mempermudah mengkonsumsi 
karena buah naga adalah buah yang mengandung kadar air tinggi maka bersifat muda rusak oleh karena itu banyak orang yang membuat olahan buah naga untuk mengurangi jumlah kerugian, adapun produk olahan yang diminati antara lain dodol, sirup, dan kripik buah naga super merah

(Hylocereus costaricensis).

Jenang merupakan makanan tradisional yang cukup popular dibeberapa daerah Indonesia. Jenang diklasifikasikan menjadi dua, yaitu jenang yang diolah dari buah-buahan dan jenang yang diolah dari tepung-tepungan, antara lain tepung beras dan tepung ketan.

\section{Rumusan Masalah}

- Apakah ada pengaruh proporsi penambahan daging buah naga super merah (Hylocereus costaricensis)

kualitas jenang dihasilkan.

- Berapakah proporsi daging buah yang paling baik sehingga menghasilkan jenang buah naga super merah (Hylocereus costaricensis) yang berkualitas.

\section{Tujuan Penelitian}

- Untuk mengetahui pengaruh proporsi penambahan daging buah naga super merah (Hylocereus costaricensis) terhadap kualitas jenang yang dihasilkan.

- Untuk mengetahui proporsi daging buah yang paling baik sehingga menghasilkan jenang buah naga super merah (Hylocereus costaricensis) yang berkualitas.

\section{Manfaat Penelitian}

Manfaat yang dapat diperoleh dari penelitian adalah sebagai salah satu alternatif bagi petani buah naga super merah (Hylocereus costaricensis) dalam memanfaatkan buah naga super merah menjadi produk olahan yang diminati orang banyak dan menghasilkan nilai ekonomis yang lebih di bandingkan dengan penjualan buah segar.

\section{Tempat dan Waktu Penelitian}

Penelitian dilaksanakan di laboratorium Pangan Fakultas Pertanian Universitas Yudharta Pasuruan dan laboratorium THP Universitas Muhammadiyah Malang pada bulan April 2012 sampai Juli 2012. 
Metode Penelitian

Percobaan dilakukan dengan menggunakan rancangan acak kelompok (RAK) dengan 5 perlakuan dan masing - masing perlakuan diulang sebanyak 3 kali.

Secara lengkap perlakuan yang diberikan adalah sebagai berikut :

- A1 :Penambahan

Buah Naga Super sebanyak $10 \mathrm{~g}$

- A2 :Penambahan Buah Naga Super Merah sebanyak $20 \mathrm{~g}$

- A3 :Penambahan Buah Naga Super sebanyak $30 \mathrm{~g}$

- A4 :Penambahan Buah Naga Super sebanyak $40 \mathrm{~g}$

- A5 :Penambahan Buah Naga Super Merah sebanyak $50 \mathrm{~g}$

\section{Pengumpulan data}

Pengumpulan data dilakukan dengan melakukan analisis karakteristik kimia yaitu kadar air dan; karakteristik fisik tekstur/kekenyalan dan karakteristik organoleptik yaitu kesukaan terhadap warna, rasa, kekenyalan dan aroma. Data yang meliputi karakteristik kimia dan fisik diperoleh dari laboratorium, sedangkan data karakteristik organoleptik diperoleh dari pengisian skor kesukaan oleh panelis minimal 20 orang. Skala nilai kesukaan mulai 1 (sangat tidak suka) sampai 8 (sangat suka).

\section{Analisa Data}

Analisa ragam dilakukan
untuk mengetahui adanya pengaruh perlakuan perbandingan proporsi penambahan daging buah naga super merah terhadap kadar air, tekstur, warna, rasa, kekenyalan dan aroma jenang yang dihasilkan.

Apabila dari hasil analisis ragam terdapat pengaruh perlakuan maka dilanjutkan dengan Uji Beda Duncan (Duncan Multiple Range Test) terhadap data kuantitatif (kadar air, tekstur,) untuk mengkaji perlakuan mana yang berbeda nyata.

Untuk parameter-parameter bersifat kualitatif yaitu kesukaan warna, rasa, kekenyalan dan aroma dilakukan analisis ragam dengan metode Friedman dan jika terdapat perbedaan antar perlakuan dilanjutkan dengan uji Friedman termodifikasi untuk mengetahui perlakuan mana yang berbeda (Basker, 1988). 


\section{Pengambilan Keputusan}

Pengambilan

keputusan

dilakukan untuk menentukan perlakuan mana yang terbaik dengan mempertimbangkan ke enam variabel tergantung tergantung tersebut. Metode pengambilan keputusan yang dipergunakan adalah metode indeks efektivitas (deGarmo, 1980) yang dimodivikasi oleh Susrini (2003) .

\section{Pelaksanaan Penelitian}

Proses pembuatan jenang buah naga super merah (Hylocereus costaricensis) diawali dengan pembuatan selai buah naga super merah yaitu pertama menimbang daging buah naga , mencuci dan menghancurkannya dengan menggunakan blender sampai benar-benar halus.
Diagram alir pembuatan selai buah naga super merah (Hylocereus costaricensis) dapat dilihat pada gambar 1.

Selanjutnya dilakukan pembuatan jenang buah naga super merah (Hylocereus costaricensis) yaitu mengupas kelapa, memarutnya dan ditambahkan air untuk diambil santannya. Jumlah air yang ditambahkan sama dengan berat kelapa parut. Setelah itu, bahan-bahan yang telah disiapkan tadi yaitu selai buah naga super merah (Hylocereus costaricensis) dan santan dicampur dalam satu wadah, kemudian ditambahkan bahan lainnya sepeti gula pasir. Diagram alir pembuatan jenang buah naga super merah (Hylocereus costaricensis) dapat dilihat pada gambar 2 . 
Jurnal Teknologi Pangan Vol.4 No.1

November2012

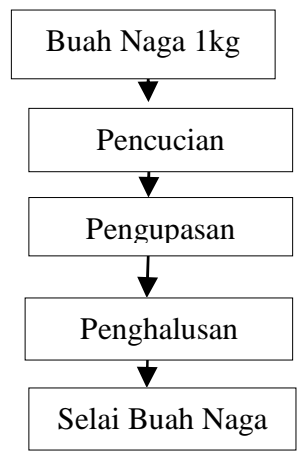

Gambar 1. Diagram Alir Pembuatan Selai Buah Naga Super Merah (Hylocereus costaricensis)

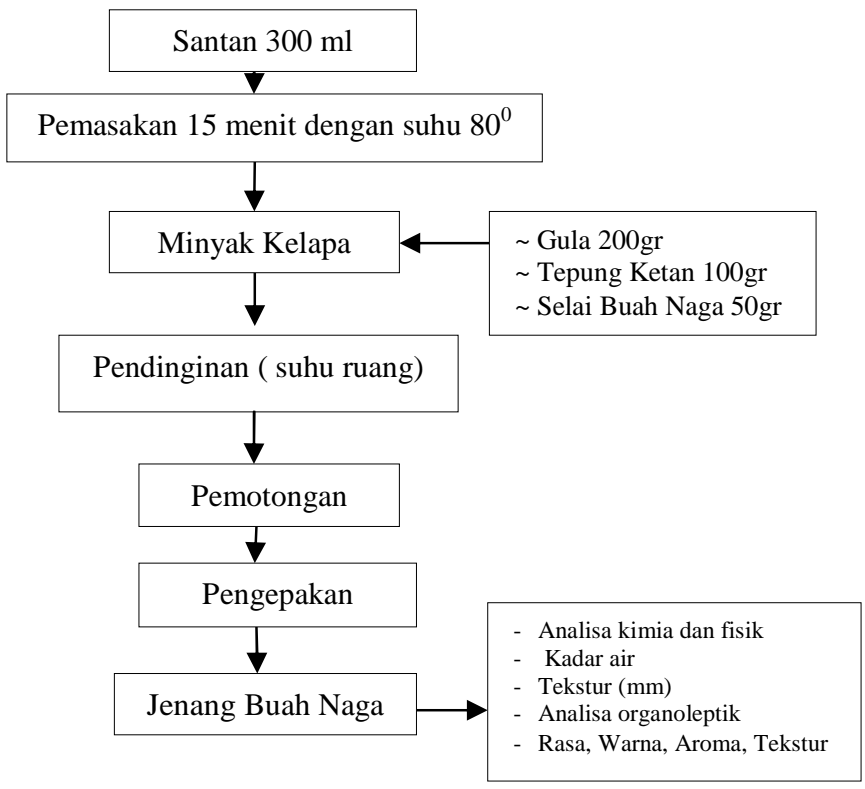

\section{Gambar 2. Diagram alir Pembuatan Jenang Buah Naga Super Merah (Hylocereus costaricensis).}


Analisa Kimia Kadar Air

Menurut

dalam bahan

merupakan

Winarno

(1992)

penting, karena air dapat mempengaruhi penampakan, tekstur, serta cita rasa makanan. Disamping itu kandungan air didalam bahan makanan ikut menentukan daya tahan bahan tersebut. Kerusakan produk pangan pada umumnya disebabkan oleh aktifitas mikroorganisme, semua jenis mikroorganisme memerlukan air untuk dapat tumbuh dan berkembang biak. Kadar air jenang buah naga super merah mempengaruhi tekstur/kekenyalan dan masa simpan produk.

Berdasarkan analisa kadar air yang dilakukan pada jenang buah naga super merah (Hylocereus costaricensis) diperoleh rata - rata kadar air antara 45,84 \% sampai $58,98 \%$. Sedangkan kadar air produk yang ada di pasar dengan merk ABATA adalah 43,12\% .

Hasil analisa sidik ragam jenang buah naga super merah menunjukkan bahwa perlakuan penambahan daging buah naga (A) mempunyai pengaruh sangat berbeda nyata (BNT 5\%) terhadap kadar air produk. Rata-rata nilai kadar air pada berbagai perlakuan ditunjukkan pada Tabel 5.

Tabel. 5. Rata-rata Kadar Air (\%) pada Berbagai Perlakuan

\begin{tabular}{|c|c|c|}
\hline $\begin{array}{c}\text { Perlakuan } \\
\text { penambahan } \\
\text { daging buah } \\
\text { naga super } \\
\text { merah }\end{array}$ & $\begin{array}{c}\text { Rata- } \\
\text { rata }\end{array}$ & Notasi \\
\hline A1 (10 gr) & 45,84 & $\mathrm{a}$ \\
\hline A2 (20 gr) & 48,61 & $\mathrm{~b}$ \\
\hline A3 (30 gr) & 51,78 & $\mathrm{c}$ \\
\hline A4 (40 gr) & 55,74 & $\mathrm{~d}$ \\
\hline A5 (50 gr) & 58,98 & $\mathrm{e}$ \\
\hline BNT 5\% & & \\
\hline
\end{tabular}

Tabel 5 menunjukkan uji BNT 5\% perlakuan terbaik kadar air diperoleh dari perlakuan (A1) yaitu penambahan daging buah naga super merah sebesar $10 \%$ sebesar 45,84\% dengan hasil yang sangat berbeda nyata dengan perlakuan yang lain. Masingmasing perlakuan menunjukkan hasil sangat berbeda nyata terhadap perlakuan yang lain. Histogram rata-rata kadar air pada berbagai perlakuan proporsi penambahan daging buah naga super merah disajikan pada Gambar 3. 


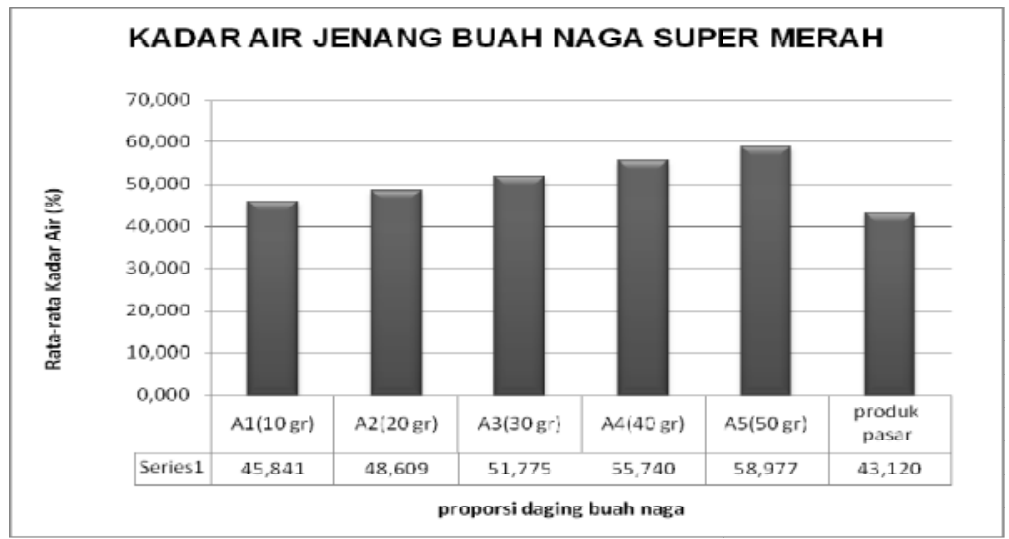

Gambar 3. Histogram rata-rata Kadar Air (\%) Berbagai Perlakuan Proporsi Penambahan Daging Buah Naga Super Merah

Gambar 3 menunjukkan bahwa kadar air tertinggi diperoleh pada perlakuan proporsi penambahan daging buah naga super merah sebesar 50 gr yaitu $58,977 \%$ dan terendah pada perlakuan proporsi penambahan daging buah naga super merah sebesar 10 gr yaitu 45,841 \%. Semakin banyak daging buah naga super merah yang ditambahkan semakin tinggi kadar air. Sebaliknya semakin sedikit daging buah naga super merah yang ditambahkan semakin sedikit kadar air jenang.

Meningkatnya kadar air dengan meningkatnya proporsi penambahan daging buah naga super merah disebabkan karena buah naga sangat tinggi kandungan airnya sehingga semakin banyak daging buah naga super merah yang ditambahkan maka semakin tinggi kadar air jenang yang dihasilkan.

Dibandingkan dengan produk yang ada di pasar yaitu jenang buah rasa apel dengan merk ABATA yang mempunyai kadar air sebesar 43,120 \% maka produk hasil penelitian mempunyai kadar air yang lebih besar yaitu $58,977 \%$, hal ini disebabkan karena buah naga super merah kandungan airnya lebih tinggi dibandingkan dengan buah apel dan pemasakan jenang buah naga 
kurang lama sehingga kadar airnya lebih tinggi. Kadar air buah apel adalah 43,120\% sedangkan kadar air buah naga super merah (Hylocereus costaricensis) adalah $58,977 \%$.

Menurut SNI No.01-42951996 tentang syarat mutu jenang disebutkan bahwa syarat mutu jenang maksimal mempunyai kadar air $20 \%$ (b/b) sedangkan produk yang dihasilkan dalam penelitian maupun produk yang ada di pasar menunjukkan kadar air diatas batas maksimal yang diperbolehkan dalam SNI No.014295-1996 hal ini disebabkan karena pemasakanya kurang lama sehingga kadar air produk jenang yang dihasilkan mempunyai kadar air yang tinggi dan tidak memenuhi syarat mutu jenang dalam SNI.

\section{Analisa Fisik}

\section{Tekstur/Kekenyalan}

Tekstur merupakan sensasi tekanan yang dapat diamati dengan melihat dan dirasakan pada waktu digigit, dikunyah, ditelan ataupun perabaan dengan jari (Kartika, 1988). Dalam pengujian fisik terhadap tekstur /kekenyalan dipakai alar berupa penetrometer.
Berdasarkan

uji tekstur/kekenyalan yang dilakukan pada jenang buah naga super merah (Hylocereus costaricensis) diperoleh rata - rata nilai tekstur antara 13,060 $\mathrm{mm}$ sampai 26,010 mm. Sedangkan nilai tekstur produk yang ada di pasar dengan merk ABATA adalah 2,43 mm.

Hasil analisa sidik ragam jenang buah naga super merah menunjukkan bahwa perlakuan penambahan daging buah naga (A) mempunyai pengaruh sangat berbeda nyata (BNT 5\%) terhadap nilai tekstur produk. Rata-rata nilai tekstur pada berbagai perlakuan ditunjukkan pada Tabel 6.

Tabel. 6. Rata-rata Nilai Tekstur (mm) pada Berbagai Perlakuan

\begin{tabular}{|c|c|c|}
\hline $\begin{array}{c}\text { Perlakuan } \\
\text { penambahan } \\
\text { daging buah } \\
\text { naga super } \\
\text { merah }\end{array}$ & $\begin{array}{c}\text { Rata- } \\
\text { rata }\end{array}$ & Notasi \\
\hline A1 (10 gr) & 4,35 & $\mathrm{a}$ \\
\hline A2 (20 gr) & 4,78 & $\mathrm{~b}$ \\
\hline A3 (30 gr) & 5,58 & $\mathrm{c}$ \\
\hline A4 (40 gr) & 6,54 & $\mathrm{~d}$ \\
\hline A5 (50 gr) & 8,67 & $\mathrm{e}$ \\
\hline BNT 5\% & & \\
\hline
\end{tabular}




$\begin{array}{lrll}\text { Masing-masing } & \text { perlakuan } & \text { tekstur pada berbagai } \\ \text { menunjukkan hasil sangat } & \text { perlakuan } & \text { proporsi } \\ \text { berbeda nyata terhadap } & \text { penambahan daging buah } \\ \text { perlakuan yang } & \text { lain. } & \text { naga super merah disajikan } \\ \text { Histogram rata-rata nilai } & \text { pada Gambar } 4\end{array}$

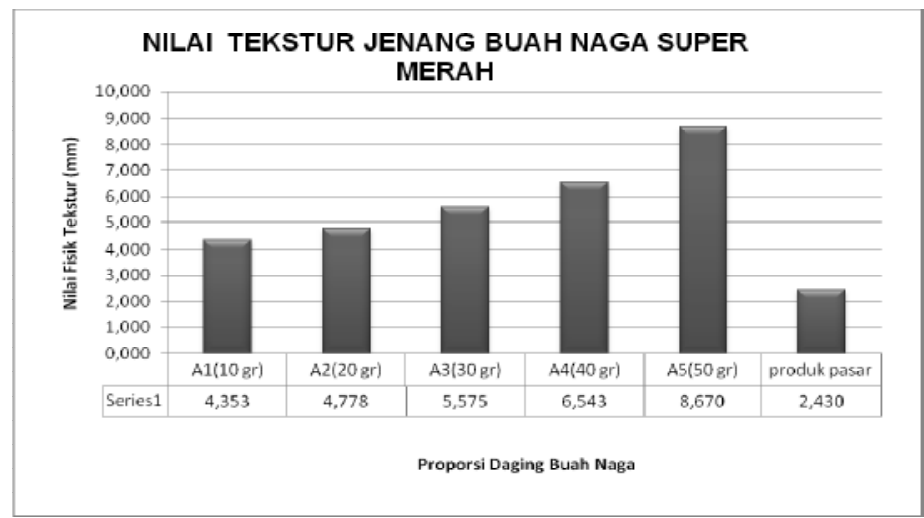

Gambar 4. Histogram rata-rata nilai tekstur (mm) Berbagai Perlakuan Proporsi Penambahan Daging Buah Naga Super Merah

Gambar 4 menunjukkan bahwa nilai tekstur tertinggi diperoleh pada perlakuan proporsi penambahan daging buah naga super merah sebesar 50 gr yaitu $8,670 \mathrm{~mm}$ dan terendah pada perlakuan proporsi penambahan daging buah naga super merah sebesar 10 gr yaitu 4,353 $\mathrm{mm}$. Semakin banyak daging buah naga super merah yang ditambahkan maka semakin besar nilai tekstur jenang yang dihasilkan atau semakin empuk. Sebaliknya semakin sedikit daging buah naga super merah yang ditambahkan semakin kecil nilai tekstur jenang atau semakin keras.

Meningkatnya nilai tekstur dengan meningkatnya proporsi penambahan daging buah naga super merah disebabkan semakin banyak daging buah naga yang ditambahkan semakin banyak kandungan airnya sehingga tekstur semakin lunak, sebaliknya semakin sedikit daging buah yang ditambahkan semakin keras 
teksturnya hal ini dikarenakan volume tepung lebih tinggi sehingga jenang lebih keras.

Dibandingkan dengan produk yang ada di pasar yaitu jenang buah rasa apel dengan merk ABATA yang mempunyai nilai tekstur sebesar 2,430 mm maka produk hasil penelitian mempunyai nilai tekstur yang lebih besar, hal ini disebabkan karena kandungan air pada buah apel lebih sedikit dibandingkan buah naga super merah dan proporsi tepung yang dicampurkan lebih besar dibanding buah apelnya.

\section{Analisa Organoleptik Jenang} Buah Naga Super Merah.

\section{Warna}

Warna merupakan salah satu parameter dalam menentukan mutu dan tingkat kesukaan konsumen. Bahan pewarna makanan terbagi dalam dua kelompok besar yakni pewarna alami dan pewarna buatan. Di Indonesia, penggunaan zat pewarna untuk makanan (baik yang diizinkan maupun dilarang) diatur dalam SK Menteri Kesehatan RI No. 235/MenKes/Per/VI/79 dan direvisi melalui SK Menteri Kesehatan
722/MenKes/Per/VI/88 mengenai bahan tambahan makanan.

Pewarna alami diperoleh dari tanaman ataupun hewan yang berupa pigmen. Beberapa pigmen alami yang banyak terdapat di sekitar kita antara lain: klorofil (terdapat pada daun-daun berwarna hijau), karotenoid (terdapat pada buah - buahan dan sayuran berwarna oranye-merah ). Umumnya, pigmen-pigmen ini bersifat tidak cukup stabil terhadap panas, cahaya, dan $\mathrm{pH}$ tertentu. Walau begitu, pewarna alami umumnya aman dan tidak menimbulkan efek samping bagi tubuh.

Pewarna buatan untuk makanan diperoleh melalui proses sintesis kimia buatan yang mengandalkan bahan-bahan kimia, atau dari bahan yang mengandung pewarna alami melalui ekstraksi secara kimiawi. Warna makanan memegang peran utama dalam penampilan makanan. Karena bila warnanya tidak menarik akan mengurangi selera orang yang memakannya. Kadang untuk mendapatkan warna yang diinginkan digunakan zat perwarna yang berasal dari berbagai bahan alam dan buatan. Dalam 
pembuatan jenang buah naga super merah ini menggunakan warna asli.

Berdasarkan pengamatan nilai organoleptik mutu warna yang dilakukan pada jenang buah naga super merah dari 5 perlakuan A1, A2, A3, A4, A5 menunjukkan mutu warna berkisar antara 4,70 sampai 5,80.
Semakin tinggi rata-rata nilai kesukaan panelis, maka tingkat kesukaan panelis terhadap warna jenang buah naga super merah semakin besar. Rata-rata tingkat kesukaan panelis terhadap warna jenang buah naga super merah ditunjukkan pada Gambar 5.

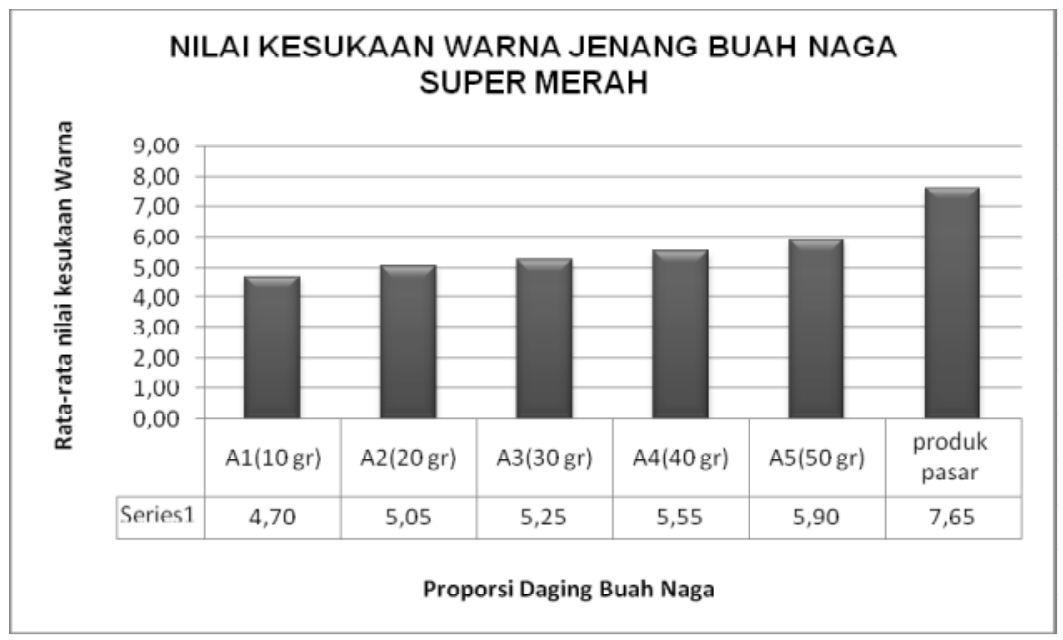

Gambar 5. Histogram Rata-rata Kesukaan Panelis Terhadap Warna Jenang Buah Naga Super Merah

Rata-rata nilai kesukaan sedangkan nilai tertinggi 5,90 panelis terhadap warna jenang didapatkan dari perlakuan proporsi buah naga super merah penambahan daging buah naga mempunyai nilai terendah 4,70 super merah sebesar $50 \mathrm{gr}$, hal ini didapatkan dari perlakuan proporsi dikarenakan perlakuan penambahan daging buah naga penambahan daging buah naga super merah sebesar 10 gr, super merah mempengaruhi warna 
jenang yang dihasilkan. Semakin banyak daging buah yang ditambahkan maka semakin terlihat warna merah dari jenang Warna merah dari buah naga super merah disebabkan karena adanya kandungan antosianin yang merupakan antioksidan dalam tubuh manusia. Menurut Kanner, J., Harel, S. dan Granit, R. (2001) antosianin dapat berfungsi untuk merendahkan kadar kolesterol dalam darah.

Nilai kesukaan warna untuk produk yang ada di pasar dengan merk ABATA lebih disukai panelis dibandingkan dengan produk hasil penelitian dengan nilai 7,65. Hal ini disebabkan karena panelis belum terbiasa melihat jenang berwarna merah sehingga ada kesan kurang bersih dan lebih suka yang berwarna kuning atau hijau. Jenang apel merk ABATA berwarna kuning sehingga panelis lebih menyukainya.

\section{Mutu Rasa}

Bahan pangan pada umumnya tidak hanya memilki salah satu rasa melainkan gabungan berbagai macam rasa secara terpadu. Rasa lebih banyak melibatkan panca indera yaitu lidah, dengan lidah senyawa dapat dikenali rasanya

Usaha untuk mendapatkan citarasa makanan yang baik dimulai sejak memilih bahan makanan yang akan digunakan dan kemudian menyiapkan bahan makanan. Pada tahap pengolahan selanjutnya digunakan berbagai cara memasak sehingga diperoleh citarasa yang di inginkan. Citarasa makanan mencakup dua aspek utama yaitu penampilan makanan sewaktu dihidangkan dan rasa makanan waktu dimakanan. Kedua aspek itu sama pentingnya untuk diperhatikan agar betul - betul dapat menghasilkan makanan yang memuaskan.

Berdasarkan pengamatan nilai organoleptik mutu rasa yang dilakukan pada jenang buah naga super merah dari 5 perlakuan A1, A2, A3, A4, A5 menunjukkan nilai mutu berkisar antara 5,45 sampai 5,85 .

Semakin tinggi rata-rata nilai kesukaan panelis, maka tingkat kesukaan panelis terhadap rasa jenang buah naga super merah semakin besar. Rata-rata tingkat kesukaan panelis terhadap rasa jenang buah naga super merah ditunjukkan pada Gambar 6. 


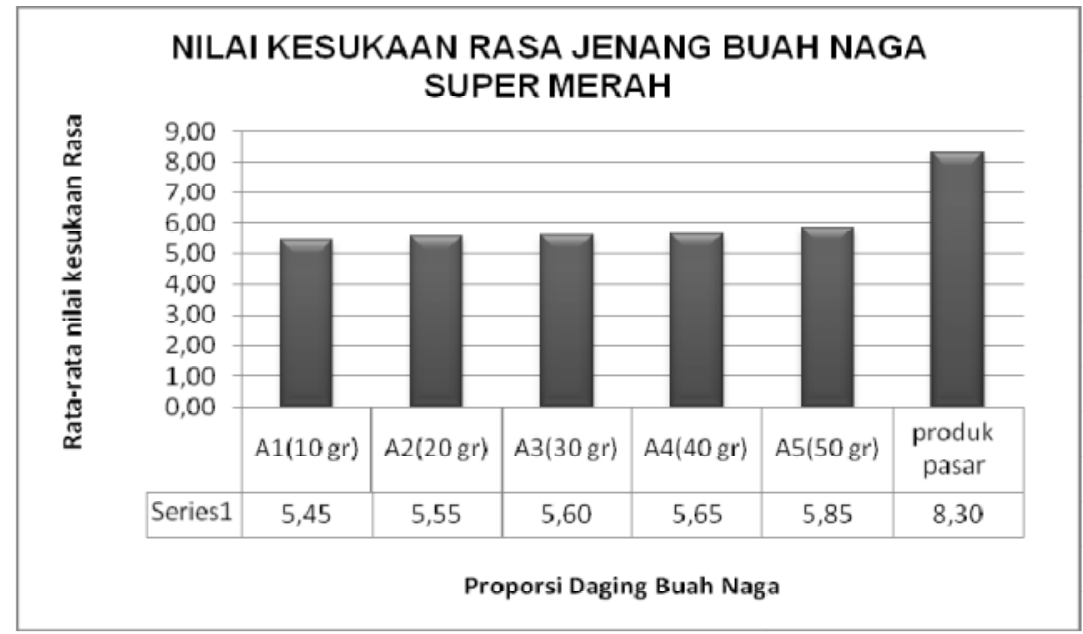

Gambar 6. Histogram Rata-rata Kesukaan Panelis Terhadap Rasa Jenang Buah Naga Super Merah

Rata-rata nilai kesukaan panelis terhadap rasa jenang buah naga super merah mempunyai nilai terendah 5,45 didapatkan dari perlakuan proporsi penambahan daging buah naga super merah sebesar 10 gr, sedangkan nilai tertinggi 5,85 didapatkan dari perlakuan proporsi penambahan daging buah naga super merah sebesar 50 gr, hal ini dikarenakan semakin banyak daging buah yang ditambahkan semakin segar rasanya karena buah naga super merah mempunyai rasa campuran asam dan manis dan disukai oleh panelis.
Nilai kesukaan rasa untuk produk yang ada di pasar dengan merk ABATA lebih disukai panelis dibandingkan dengan produk hasil penelitian dengan nilai 8,30. Hal ini disebabkan karena panelis belum terbiasa merasakan jenang buah naga super merah sehingga kurang bisa menerima rasanya dibandingkan dengan jenang apel yang sudah terbiasa dirasakan .

\section{Aroma}

Aroma merupakan indikator yang penting dalam industri pangan karena dengan cepat dapat 
memberikan hasil penilaian diterima atau tidaknya produk tersebut. Aroma ("odour") meliputi berbagai sifat seperti harum, amis, apek, busuk, dan sebagainya.

Aroma atau bau sendiri sukar untuk diukur sehingga biasanya menimbulkan pendapat yang berlainan dalam menilai kualitas aromanya (Hambali, 2004). Perbedaan pendapat disebabkan tiap orang memiliki perbedaan penciuman meskipun mereka dapat membedakan aroma namun setiap orang mempunyai kesukaan yang berlainan.
Berdasarkan pengamatan nilai organoleptik mutu aroma yang dilakukan pada jenang buah naga super merah dari 5 perlakuan A1, A2, A3, A4, A5 menunjukkan nilai mutu berkisar antara 4,65 sampai 4,85 .

Semakin tinggi rata-rata nilai kesukaan panelis, maka tingkat kesukaan panelis terhadap rasa jenang buah naga super merah semakin besar. Rata-rata tingkat kesukaan panelis terhadap aroma jenang buah naga super merah ditunjukkan pada Gambar 7.

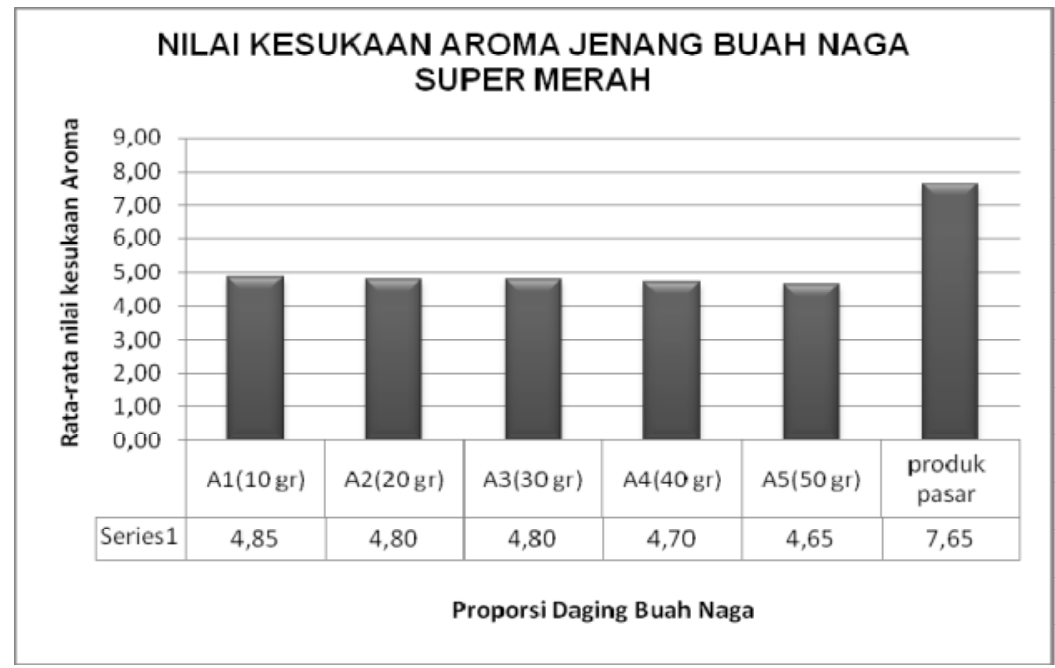

Gambar 7. Histogram Rata-rata Kesukaan Panelis Terhadap Aroma Jenang Buah Naga Super Merah 
Rata-rata nilai kesukaan panelis terhadap aroma jenang buah naga super merah mempunyai nilai terendah 4,65 didapatkan dari perlakuan proporsi penambahan daging buah naga super merah sebesar 50 gr, sedangkan nilai tertinggi 4,85 didapatkan dari perlakuan proporsi penambahan daging buah naga super merah sebesar $10 \mathrm{gr}$, hal ini dikarenakan semakin banyak daging buah naga yang ditambahkan aromanya semakin langu.

Nilai kesukaan aroma untuk produk yang ada di pasar dengan merk ABATA lebih disukai panelis dibandingkan dengan produk hasil penelitian dengan nilai 7,65. Hal ini disebabkan karena jenang buah apel lebih wangi disbanding jenang buah naga yang terasa langu.

\section{Tekstur}

Tekstur merupakan sensasi tekanan yang dapat diamati dengan melihat dan dirasakan pada waktu digigit, dikunyah, ditelan ataupun perabaan dengan jari (Hambali, 2004). Tekstur secara langsung dapat dilihat kenampakannya (dari luar) oleh konsumen sehingga berpengaruh terhadap penilaian diterima atau tidaknya produk tersebut. Tekstur (konsistensi) adalah hasil pengamatan yang berupa sifat lunak, liat, keras, halus, kasar, dan sebagainya.

Berdasarkan pengamatan nilai organoleptik mutu tekstur yang dilakukan pada jenang buah naga super merah dari 5 perlakuan A1, A2, A3, A4, A5 menunjukkan nilai mutu berkisar antara 5,00 sampai 5,40 .

Semakin tinggi rata-rata nilai kesukaan panelis, maka tingkat kesukaan panelis terhadap tekstur jenang buah naga super merah semakin besar. Rata-rata tingkat kesukaan panelis terhadap tekstur jenang buah naga super merah ditunjukkan pada Gambar 8. 
Jurnal Teknologi Pangan Vol.4 No.1

November2012

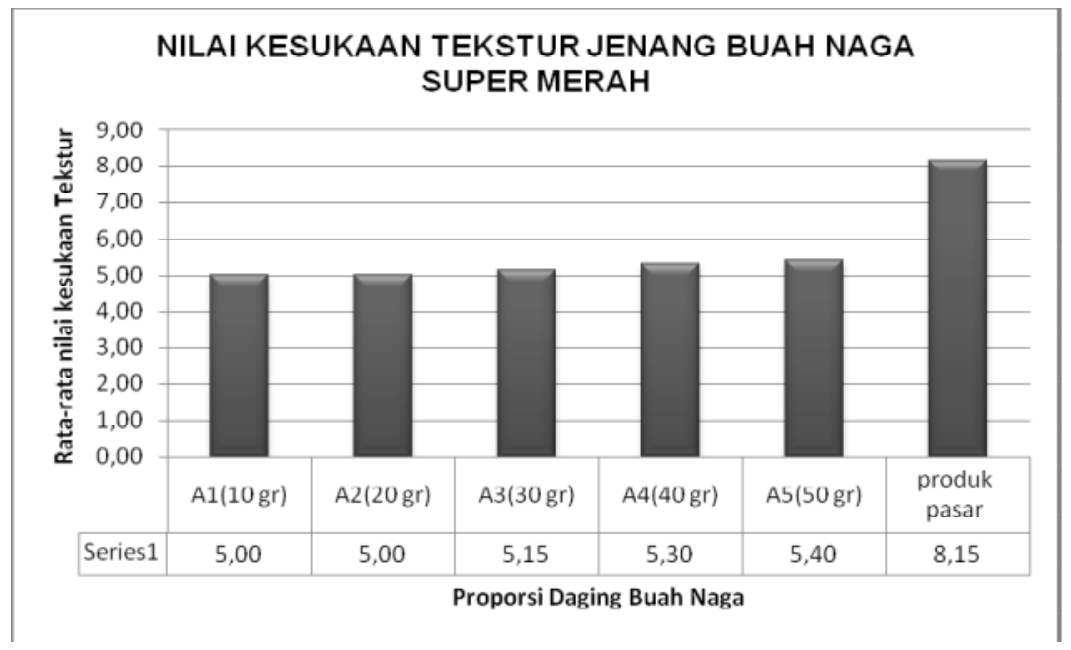

Gambar 8. Histogram Rata-rata Kesukaan Panelis Terhadap Tekstur Jenang Buah Naga Super Merah

Rata-rata nilai kesukaan panelis terhadap tekstur jenang buah naga super merah mempunyai nilai terendah 5,00 didapatkan dari perlakuan proporsi penambahan daging buah naga super merah sebesar 10 gr, sedangkan nilai tertinggi 5,40 didapatkan dari perlakuan proporsi penambahan daging buah naga super merah sebesar $50 \mathrm{gr}$, hal ini dikarenakan jenang buah naga dengan proporsi 50 gr mempunyai tekstur yang lebih empuk sehingga panelis menyukai.
Nilai kesukaan tekstur untuk produk yang ada di pasar dengan merk ABATA lebih disukai panelis dibandingkan dengan produk hasil penelitian dengan nilai 8,15. Hal ini disebabkan karena jenang buah apel sudah sangat dikenal di pasaran sehingga bisa mempengaruhi persepsi panelis terhadap teksturnya padahal tekstur jenang buah naga jauh lebih empuk dan kenyal.

Pemilihan alternatif terbaik penelitian dengan indek efektivitas 
Penentuan perlakuan terbaik serta uji organoleptik, rasa, warna, jenang buah naga super merah aroma dan tekstur. Bobot dilakukan dengan menggunakan parameter tertinggi adalah rasa metode indeks efektivitas (De dengan bobot 0,274 diikuti Garmo, Sullivan dan Canada, masing-masing warna 0,226 ; 1984) yang dimodifikasi oleh aroma 0,190 ; kekenyalan (fisik) Susrini . Metode ini dilakukan 0,157 ; tekstur orleb 0,086 dan pada parameter kimiawi meliputi kadar air 0,067. Bobot parameter uji kadar air, parameter fisik disajikan pada Gambar 9 . meliputi uji tekstur/kekenyalan

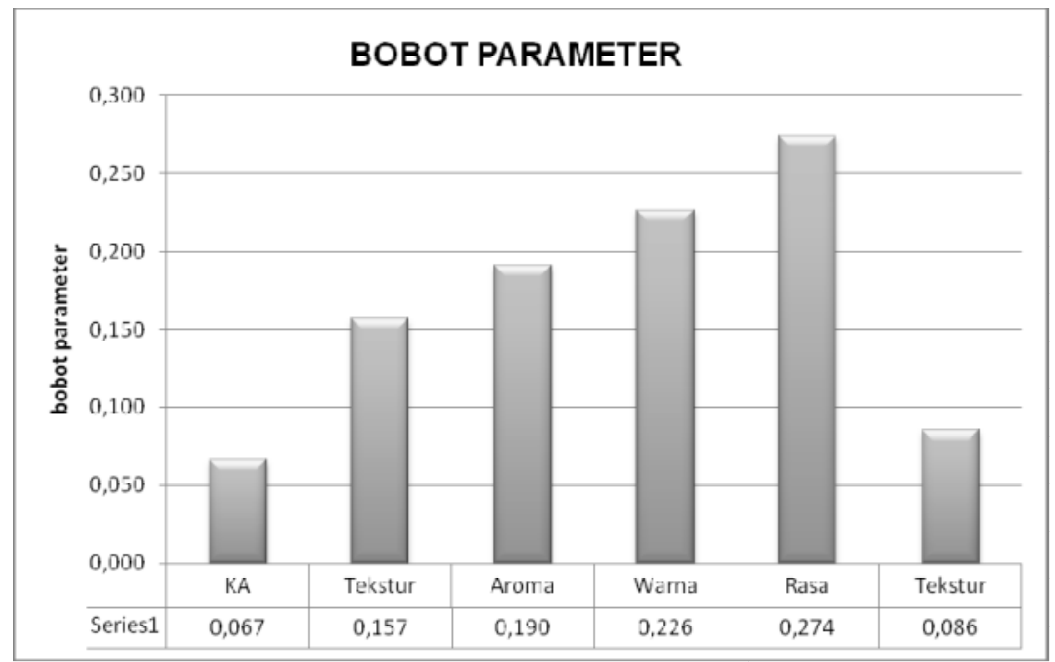

Gambar 9. Bobot parameter Uji Indeks Efektivita

Sedangkan penilaian naga super merah disajikan pada perlakuan terbaik jenang buah Tabel 7. 
Tabel 7. Penilaian perlakuan terbaik terhadap parameter kimiawi, fisik dan organoleptik pada jenang buah naga super merah perlakuan proporsi penambahan daging buah naga super merah.

\begin{tabular}{|l|c|}
\hline \multicolumn{1}{|c|}{ Jenang buah naga super merah } & Nilai Produk \\
\hline Proporsi penambahan danging buah naga 10 gr (A1) & 0,073 \\
\hline Proporsi penambahan danging buah naga 20 gr (A2) & 0,128 \\
\hline Proporsi penambahan danging buah naga 30 gr (A3) & 0,186 \\
\hline Proporsi penambahan danging buah naga 40 gr (A4) & 0,252 \\
\hline Proporsi penambahan danging buah naga 50 gr (A5) & 0,365 \\
\hline Produk di pasar merk ABATA & $\mathbf{0 , 7 7 6}$ * \\
\hline
\end{tabular}

$*$ = perlakuan terbaik

Hasil menunjukkan perlakuan terbaik pada penelitian pembuatan jenang buah naga super merah diperoleh dari jenang buah naga super merah dengan proporsi penambahan daging buah naga super merah sebesar 50 gr dengan karakteristik sebagai berikut: rata-rata kadar air $58,98 \%$; nilai fisik tekstur 8,67.mm serta rata-rata tingkat kesukaan panelis terhadap rasa 5,85; warna5,90 aroma 4,65 dan tekstur 5,40 .

Dari hasil analisa indeks efektivitas de Garmo yang dimodifikasi Susrini menunjukkan bahwa kualitas terbaik didapatkan oleh produk yang dipasarkan dengan merk ABATA.
Kesimpulan

- Terdapat pengaruh proporsi penambahan daging buah naga super merah (Hylocereus costaricensis) terhadap kualitas jenang yang dihasilkan yaitu semakin banyak proporsi penambahan daging buah naga super merah (Hylocereus costaricensis) maka kualitas jenang yang dihasilkan semakin baik.

- Proporsi penambahan daging buah naga super merah (Hylocereus costaricensis) yang paling baik adalah perlakuan A5 yaitu proporsi penambahan daging buah naga super merah sebesar $50 \mathrm{gr}$ dengan karakteristik kadar air sebesar 58,977\%; tektur 8,67 $\mathrm{mm}$; nilai kesukaan rasa 5,85 
nilai kesukaan warna 5,90; nilai kesukaan aroma 4,65 dan nilai kesukaan tekstur 5,40

\section{Saran}

Dari hasil penelitian dapat disarankan perlunya penelitian lanjutan tentang kandungan antioksidan, lama dan suhu pemasakan persentase tepung yang ditambahkan serta penambahan santan pada pembuatan jenang buah naga sehingga dapat dihasilkan produk yang memenuhi standar SNI dan layak untuk dipasarkan.

\section{DAFTAR PUSTAKA}

Anonymous ， 1990. Komposisi

Zat Gizi Indonesia. Depkes

RI Direktorat Bina Gizi

Masyarakat dan Pusat Litbang Gizi, Jakarta.

\section{Hylocereus}

polyrhizus Buah Naga. Jabatan Pertanian Sabah.

Unit Perkhidmatan

Pengembangan Pertanian

.Pejabat Pertanian Tawau. 2008. Turunkan

Kolesterol dengan Buah Naga.

http://www.egamesbox.com.

Mei.
2008. Buah naga. http://www.wikipedia.org/bua h naga. Mei.

2003, Hasilkan Buah Naga Kualitas Prima, trubus, bonus Mei.

Ariyanto, H, 2006. Budidaya Tanaman Buah - buahan. PT. Citra aji parmana. Yogyakarta.

Astawan, W, 1991. Teknologi Pengolahan Pangan Nabati Tepat Guna. Akademi Pressindo. Jakarta.

Buckle, K.A, R.A. Edward, G.H. Fleet, dan M. Wooton. 1987, Ilmu Pangan. Universitas Indonesia Press, Jakarta.

deMan JM. 1989, Kimia Makanan. Padmawinata K, penerjemah. Bandung Institut Teknologi Bandung. Terjemahan dari: Principles of Food Chemistry. hlm 190-212.

Escribano, J., Pedreño, M.A., Garcia-Carmona, F. \& Muñoz, R. 1998, Characterization of the Antiradical Activity of Betalains from Beta Vulgaris L. Roots. Phytochemical Analysis 9: 124-127. 
Faridi H. 1994. The Science of Cookie and Cracker Production. New York:

Fennema, O.R. 1976. Foog Chemestry. Department of Food Science and Human Nutrition Michigan State University, East Lansing, Michigan

Glicksman M., 1983. Gum Technology in the Food Industry. New York: Academic Press. p 214- 224.

Goutara dan Wijandi, 1975. Dasar Pengolahan Gula. IPB. Bogor.

Hambali, Erliza, 2004. Membuat Aneka Olahan Rumput Laut. Penebar

Swadaya . Jakarta.

Hastuti D. R. dan Rahim A., 2007.

Ekonomika Pertanian (pengantar, Teori, dan kasus). Penebar Swadaya. Jakarta.

Hellebust JA, Cragie JS, 1978.

Handbook of Phycological Methods. London:Cambridge University Press. p 54-66.

Hui, Y. H. 1992. Encyclopedia Of Food Science And Technology. Vol 3. John Wiley And Sons, Inc. New York.
Irawan, Yuni, 2010. Buah Naga (Dragon Fruit) Solusi Sehat Tanpa Obat. http://bisnisukm.com/buahnaga-dragon-fruit-solusisehat-tanpa-obat.html.

Diakses pada tanggal 17 Oktober 2011

Kanner, J. Harel, S. \& Granit, R., 2011. Betalains. A New Class of Dietary Cationized Antioxidants. J. Agr. Food Chem. 49 : 51785185

Kristanto, D., 2008. Buah Naga Pembudidayaan di Pot dan di Kebun. Penebar Swadaya. Jakarata

Langseth, Lilian. 1995. Oxidant, Antioxidant, and Disease Prevention. International Life Science Institute press. Belgium.

Luthony, T .H. 1993. Tanaman Sumber Pemanis. penembar

Middleton Jr, E., Kandaswami, C., 1994. The Impact of Plant Flavonoid on Mammalian Biology : Implication for Immunity, Inflammation and Cancer. In: Harborne, J.B, The Flavonoid: Advances in Research Since 
1986. Chapman \& Hall. Satiawihardja, B. 1994. Makanan

London. 619-652.

Mohamed, S. 1985.Food Semi Basah Menurut

Technology In Malaysia.

Seminar of Food

Technology and Nutrition. Gadjah Mada

Universiti.Yogyakarta.

Munadjim. 1983. Teknologi

Pengolahan. Gramedia,

Jakarta

Munasir, dkk. 1987. Penambahan

Tepung Beras Ketan Putih

Pada Pembuatan Geplak.

PAU Pangan dan Gizi

UGM. Yogyakarta.

Susanto dan Saneto. 1994.

Teknologi Pengolahan Hasil

Pertanian. PT. Bina

Ilmu. Surabaya.

Selera Dan Tahan Lama.

Femina No. 39/XXII 6-12

Oktober Hal 98-100. Jakarta

Sherrington. 1981. Pengantar

Ilmu Pangan Nutrisi Dan

Mikrobiologi. Gajah Mada

University Press, Yogyakarta.

Sukamto, M. Haris, Dragon Fruit :

Buah Nyeleneh dari

Guyana. http : //

www.Tanindo.com/abdi14/

hal 2601.htm. Diakses pada

tanggal 17 Maret 2000.

Sutomo, Budi. 2007. Buah Naga

Merah - Segar dan Berkhasiat.

http://myhobbyblogs.com

Wanda, widi. 2010. Buah Naga.

http://wandawidi.blogspot.co

Buah Naga.

http://www.buahnaga.us/2009

/04/khasiat-buah-naga.html.

Diakses pada tanggal 17

Oktober 2011.

$\mathrm{m} / 2010 / 07 /$ khasiat buah-

naga.html. Diakses pada

tanggal 17 Oktober 2011

Winarno FG, 1988. Kimia Pangan

Dan Gizi. PT. Gramedia,

Rukmana, Rahmad, Ir. Dan $\mathrm{Hj}$. jakarta.

Yuyun Yuaningsih Oesman,

B.Sc. , 2003. Kaktus, Cet.S,

Kanisius, Yogyakarta. 